\title{
SISTEM PENDUKUNG KEPUTUSAN PENERIMA BANTUAN BEDAH RUMAH MENGGUNAKAN METODE ANALITYCAL HIERARCHY PROSESS (AHP) DAN MULTI OBJECTIVE OPTIMIZATION ON THE BASIS OF RATIO ANALYSIS
}

\author{
M. Abu Jihad Plaza $\mathbf{R}^{1}$, Chandra $\operatorname{Irawan}^{2}$ \\ ${ }^{12}$ Program Studi Teknik Informatika, ${ }^{2}$ Program Studi Sistem Informasi \\ STMIK Surya Intan \\ Jl. Ibrahim Syarief No. 107, Kotabumi, Lampung Utara \\ Email : abujihad83@gmail.com, chandra.irawan17@gmail.com
}

\begin{abstract}
The house renovation program is one of the government's strategies in helping underprivileged residents have a livable house. Determining whether or not a family has the right to receive house renovation assistance requires a selection process that runs very slowly and is considered less efficient in terms of time and cost and is deemed ineffective. In this study, two methods are applied, namely the Analytical Hierarchy Process (AHP) is used for calculating the weight of each criterion and the Multi Objective Optimization on The Basis of Ratio Analysis MOORA for ranking values. Based on the results of the application of the AHP and MOORA methods in the decision support system for receiving house renovation assistance with the criteria for the number of dependents, house status, house condition, BSPS status, income and preparation to build a house with an eligibility status of more than or equal to 0.25 feasible and less than 0,25 is not.
\end{abstract}

Keywords - Decision Support System, Analytical Hierarchy Process, Multi Objective Optimization on The Basis of Ratio Analysis

\begin{abstract}
ABSTRAK
Program bedah rumah adalah salah satu strategi pemerintah dalam membantu warga yang kurang mampu dan memiliki rumah layak huni. Dalam menentukan berhak dan tidaknya keluarga untuk mendapatkan bantuan bedah rumah memerlukan proses penyeleksian yang berjalan sangat lambat dan dinilai kurang efisien dari segi waktu dan biaya serta dirasa kurang efektif. Pada penelitian ini menerapkan dua metode yaitu Analytical Hierarchy Process (AHP) untuk perhitungan bobot tiap kriteria dan Multi Objective Optimization on The Basis of Ratio Analysis MOORA digunakan untuk nilai perangkingan. Berdasarkan hasil penerapan metode AHP dan MOORA dalam sistem penunjang keputusan penerimaan bantuan bedah rumah dengan kriteria jumlah tanggungan, status rumah, kondisi rumah, status BSPS, penghasilan dan persiapan membangun rumah dengan status kelayakan lebih dari atau sama dengan 0,25 Layak dan kurang dari 0,25 tidak layak.
\end{abstract}

Kata Kunci-Sistem Penunjang Keputusan, Analytical Hierarchy Process, Multi Objective Optimization on The Basis of Ratio Analysis 


\section{Pendahuluan}

Program bedah rumah merupakan strategi yang dilakukan oleh pemerintah yang dilakukan oleh pihak Dinas Perumahan dan Kawasan Pemukiman Lampung Utara untuk membantu kemiskinan dengan maksud penduduk miskin memiliki rumah yang layak huni, sasaran program bedah rumah adalah warga yang kurang mampu dan memiliki rumah yang tidak layak huni.

Bantuan bedah rumah pada Kelurahan Kelapa Tujuh Kotabumi di mulai dari tiap-tiap RT, Selama ini lurah yang menentukan berhak dan tidaknya keluarga untuk mendapatkan bantuan bedah rumah berdasarkan berkas yang diterima dari RT, berkas tersebut diverifikasi dan divalidasi secara manual, sehingga proses penyeleksian ini berjalan sangat lambat dan dinilai kurang efisien dari segi waktu dan biaya serta dirasa kurang efektif.

Sebuah sistem pendukung keputusan diharapkan dapat digunakan untuk membantu proses penilaian dengan lebih tepat dan akurat dalam proses seleksi penerima bantuan bedah rumah.

Pada penelitian - penelitian sebelumnya dengan permasalahan serupa antara lain : penelitian yang mengangkat masalah tentang penentuan kelompok prioritas penerima bantuan bedah rumah menggunakan metode Clustering $K$ Means. Terdapat kerumitan dalam pengolahan data yang ditemui, yaitu menentukan penduduk miskin yang menjadi prioritas utama untuk mendapatkan bantuan ditengah banyaknya data penduduk miskin di Kecamatan Bahar Utara. Kerumitan tersebut muncul karena dari besarnya jumlah penduduk miskin yang ada, Camat harus mempertimbangkan berapa criteria diantaranya Status Kesejahteraan, Status Penguasaan Bangunan Tempat Tinggal, Jenis Atap, Jenis Lantai, Jenis Dinding, dan Jumlah Individu dalam sebuah keluarga [1]. Metode AHP juga diterapkan untuk [2] mendapatkan nilai bobot dari kriteria dan alternatif, sehingga diperoleh hasil akhir dengan perangkingan nilai bobot tertinggi yang bertujuan membantu merekomendasikan kepada konsumen dalam pemilihan produk handphone yang sesuai keinginan, kegunaan dan anggarannya. Metode Analitycal Hierarchy Process (AHP) adalah suatu model pengambilan keputusan yang komprehensif dan terstruktur [3]. Hasil penelitian menunjukkan bahwa sistem yang dibangun mampu memberikan hasil perhitungan secara otomatis sesuai dengan hasil perhitungan yang dilakukan secara 
manual. Diharapkan dengan sistem yang dirancang dapat membantu pengambil keputusan yang bersifat objektif dan pada proses penilaian kinerja pegawai yang lebih efisien. Penerapan metode MOORA dalam penentuan ranking kenaikan gaji staff dan karyawan, dimana kelebihan MOORA adalah memiliki tingkat selektifitas yang baik karena dapat menentukan tujuan dari kriterian yang bertentangan [4].

Penggabungan dua metode AHP dan MOORA diharapkan dapat memberikan penilaian yang lebih akurat berdasarkan dari penilaian terhadap setiap kriteria dan subkriteria yang digunakan.

\section{Metode Penelitian}

Dalam penelitian ini mengkombinasikan dua metode penelitian yaitu :

\section{1. Analytical Hierarchy Process (AHP)}

AHP merupakan metode untuk membuat urutan alternatif yang bertujuan untuk memilih yang terbaik pada saat pengambilan keputusan. Dalam AHP adakalanya timbul masalah keputusan yang dirasakan dan diamati perlu diambil secepatnya tetapi variasinya rumit sehingga datanya tidak mungkin dapat dicatat secara numerik [5].

Langkah-langkah dan prosedur dalam menyelesaikan persoalan dengan menggunakan metode AHP sebagai berikut :

1. Mendefinisikan masalah kemudian menentukan solusi dan menyusun hierarki dari permasalahan yang dihadapi.

2. Menentukan bobot kriteria dengan membandingkan secara berpasangan tiap kriteria yang terlihat pada Tabel 1 .

Tabel 1. Skala Penilaian

\begin{tabular}{|c|c|c|}
\hline Kepentingan & Defenisi & Penjelasan \\
\hline 1 & $\begin{array}{l}\text { Kedua elemen sama } \\
\text { pentingnya }\end{array}$ & Dua elemen mempunyai pengaruh yang sama besar \\
\hline 3 & $\begin{array}{l}\text { Elemen yang satu sedikit } \\
\text { lebih penting dari pada } \\
\text { elemen yang lainnya }\end{array}$ & $\begin{array}{l}\text { Pengalaman dan penilaian sedikit menyokong satu elemen } \\
\text { dibandingkan elemen yang lainnya }\end{array}$ \\
\hline 5 & $\begin{array}{l}\text { Elemen yang satu lebih } \\
\text { penting daripada yang } \\
\text { lainnya }\end{array}$ & $\begin{array}{l}\text { Pengalaman dan penilaian sangat kuat menyokong satu } \\
\text { elemen dibandingkan elemen yang lainnya }\end{array}$ \\
\hline 7 & $\begin{array}{l}\text { Satu elemen jelas lebih } \\
\text { mutlak penting daripada } \\
\text { elemen Lainnya }\end{array}$ & $\begin{array}{l}\text { Satu elemen yang kuat disokong dan dominan terlihat dalam } \\
\text { praktek }\end{array}$ \\
\hline 9 & $\begin{array}{l}\text { Satu elemen mutlak } \\
\text { penting dari pada elemen } \\
\text { lainnya }\end{array}$ & $\begin{array}{l}\text { Bukti yang mendukung elemen yang satu terhadap elemen } \\
\text { lain memiliki tingkat penegasan tertinggi yang mungkin } \\
\text { menguatkan }\end{array}$ \\
\hline $2,4,6,8$ & $\begin{array}{l}\text { Nilai-nilai antara dua } \\
\text { nilai pertimbangan- } \\
\text { pertimbangan yang } \\
\text { berdekatan }\end{array}$ & Nilai ini diberikan bila ada dua kompromi diantaradua pilihan \\
\hline
\end{tabular}


Kebalikan $\quad$ Jika untuk aktivasi i mendapat satu angka dibanding dengan aktivasi j, maka j mempunyai nilai kebalikannya dibanding dengan $\mathrm{i}$.

3. Normalisasi terhadap matriks perbandingan berpasangan. Adapun langkah-langkah normalisasi matriks sebagai berikut :

a. Menjumlahkan nilai-nilai dari setiap kolom pada matriks perbandingan berpasangan.

b. Membagi setiap nilai dari kolom dengan hasil penjumlahan kolom yang bersangkutan untuk memperoleh normalisasi matriks. Rumus perhitungan normaliasi matriks menggunakan persamaan (1) dibawah ini :

$\bar{a}_{j k}=\frac{a_{j k}}{\sum_{l=1}^{m} a_{l k}}$

4. Menghitung jumlah baris dengan cara menjumlahkan tiap kolom pada baris yang sama dari hasil normalisasi matriks perbandingan.

5. Menghitung bobot prioritas tiap kriteria dengan jumlah baris untuk tiap kriteria dibagi dengan jumlah kriteria.

6. Menghitung lamda tiap kriteria dengan cara perkalian matrik dengan bobot prioritas.

7. Menghitung nilai eigen maksimum dengan cara total jumlah lamda dibagi banyaknya kriteria.
8. Mengukur konsistensi untuk memastikan bahwa pertimbanganpertimbangan untuk pengambilan keputusan memiliki konsistensi tinggi. Langkah-langkah dalam mengukur konsistensi yaitu :

a. Menghitung Consistency Index (CI) yang ditunjukkan Persamaan (2).

$C I=\frac{(\lambda m a k s-n)}{n-1}$

Keterangan :

CI : Consistency Index

$\lambda$ maks $\quad$ : eigen maksimum

n : banyaknya elemen

b. Menghitung Consistency Ratio (CR) yang ditunjukkan Persamaan (3).

$C R=\frac{C I}{I R}$

Keterangan :

CR : Consistency Ratio

CI : Consistency Index

IR : Index Random Consistency

9. Memeriksa konsistensi hierarki rasio konsistensi (CI/IR) bernilai kurang dari atau sama dengan 0,1 maka hasil perhitungan dapat dinyatakan benar, terlihat pada tabel 2 .

Tabel 2. Nilai indeks Random

\begin{tabular}{|c|c|}
\hline Ukuran Matrik & Indeks Random \\
\hline 1,2 & 0 \\
\hline 3 & 0,58 \\
\hline 4 & 0,9 \\
\hline 5 & 1,12 \\
\hline
\end{tabular}




\begin{tabular}{|c|c|}
\hline 6 & 1,24 \\
\hline 7 & 1,32 \\
\hline 8 & 1,41 \\
\hline 9 & 1,45 \\
\hline 10 & 1,49 \\
\hline
\end{tabular}

\subsection{Multi Objective Optimization on the}

basis of Ratio Analysis.

Multi Objective Optimization on the basis of Ratio Analysis adalah sistem multi-objektif yang mengoptimalkan dua atau lebih attribut yang saling bertentangan secara bersamaan. Metode ini diterapkan untuk memecahkan masalah dengan perhitungan matematika yang kompleks [6]. Langkah-langkah yang dilakukan dalam menyelesaikan suatu permasalahan menggunakan metode MOORA adalah sebagai berikut :

1. Membuat matriks keputusan dengan persamaan (4).

$$
X=\begin{array}{lll}
X_{11} & X_{12} & X_{1 n} \\
X_{21} & X_{22} & X_{2 n} \\
X_{31} & X_{32} & X_{3 n}
\end{array}
$$

2. Matriks Normalisasi dapat dilihat dari persamaan (5).

$$
X_{J}^{*}=\frac{\mathrm{Xij}^{\mathrm{ij}}}{\sqrt{\sum_{i=1}^{m} X_{i f}^{Z}(j=1,2, \ldots, n)}}
$$

3. Mengoptimalkan Atribut.

Ada dua cara yang dapat dilakukan yaitu :

a. Jika atribut atau kriteria pada masing-masing alternatif tidak diberikan nilai bobot dengan persamaan (6). $y=\sum_{j=1 X_{i j}^{*}}^{g}-\sum_{j=g+1}^{n} x_{I j}^{*}$ b. Jika atribut atau kriteria pada masing-masing alternatif di berikan nilai bobot kepentingan dengan persmaan (7).

$y=\sum_{j=1 w_{j} x_{i j}^{*}}^{g}-\sum_{j=g+1 w_{j}}^{n} x_{I j(j=1,2, \ldots, n)}^{*}(7)$

4. Perangkingan Nilai Y.

Nilai Y bisa positif atau negatif tergantung dari total maksimal dan minimal dalam matriks keputusan. Sebuah urutan peringkat dan Yi menujukan pilihan terakhir. Dengan demikian alternatif terbaik memiliki nilai Yi tertinggi, sedangkan alternatif terburuk memiliki nilai yang rendah.

\section{HASIL}

Adapun tahapan - tahapan yang dilakukan dapat dilihat pada gambar 1 .

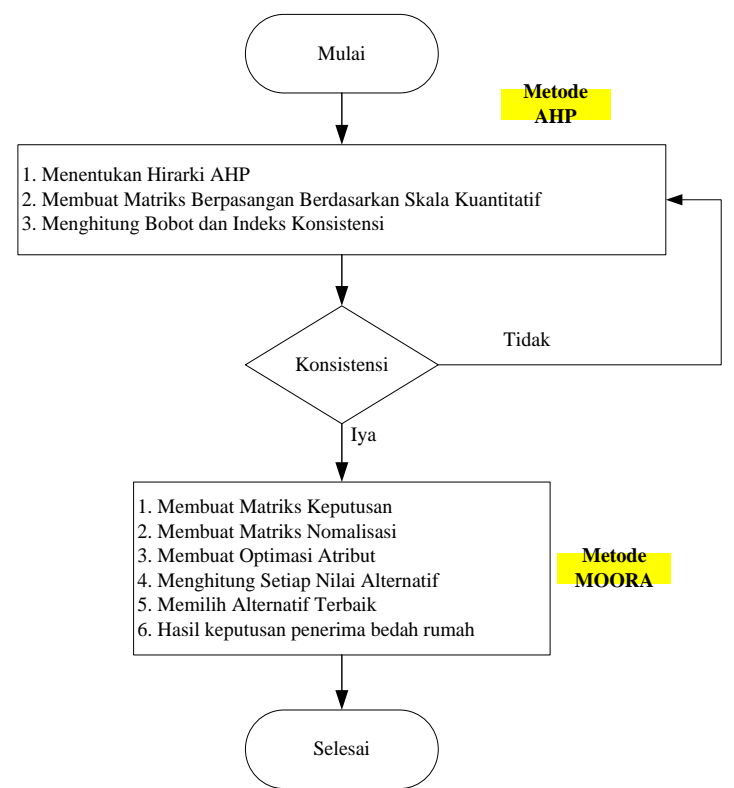

\section{Gambar 1. Flowchart AHP dan MOORA}

\subsection{Tahapan Metode AHP.}


Pada metode AHP ini digunakan untuk mendapatkan nilai bobot kepentingan kriteria, langkah langkahnya sebagai berikut :
1. Hiraki Penerima Bedah Rumah

Tahap pertama adalah membuat hirarki penerima bantuan bedah rumah, terlihat pada gambar 2 dibawah ini.

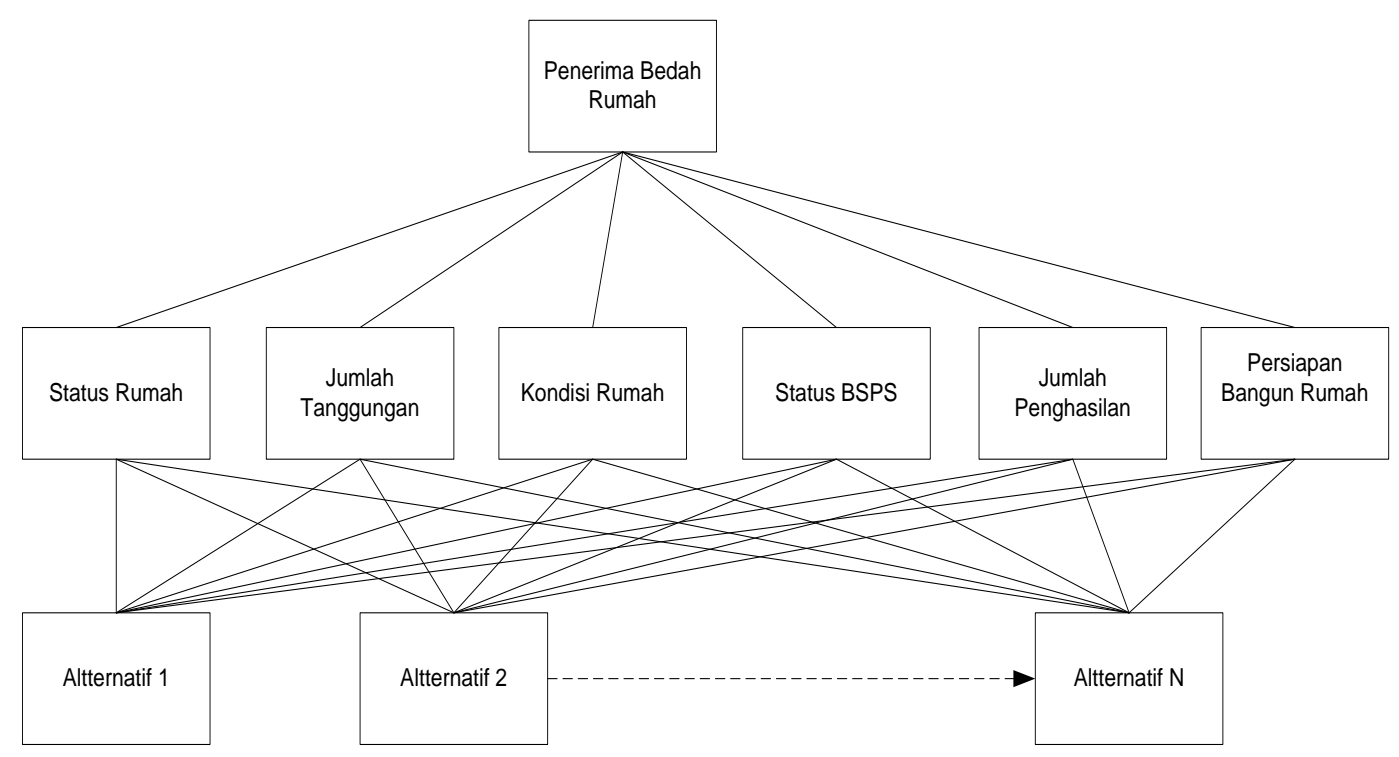

Gambar 2. Hirarki Penerima Bedah Rumah

2. Kriteria dan Subkriteria.

Dalam penelitian ini dibutuhkan informasi berupa kriteria dan subkriteria calon penerima bedah rumah. Kriteria dan subkriteria yang digunakan dapat dilihat pada tabel 3 .

\section{Tabel 3. Kriteria dan Subkriteria}

\begin{tabular}{|l|l|c|}
\hline \multicolumn{1}{|c|}{ Kriteria (C) } & \multicolumn{1}{|c|}{ Sub Kriteria } & \multicolumn{1}{|c|}{$\begin{array}{c}\text { Bobot } \\
\text { Nilai }\end{array}$} \\
\hline \multirow{2}{*}{$\begin{array}{l}\text { Status } \\
\text { Rumah (C1) }\end{array}$} & Sendiri & 5 \\
\cline { 2 - 3 } & Milik Orang Tua & 2 \\
\cline { 2 - 3 } & Kontrak & 1 \\
\hline \multirow{2}{*}{$\begin{array}{l}\text { Status BSPS } \\
\text { (C2) }\end{array}$} & Belum Pernah & 5 \\
\cline { 2 - 3 } $\begin{array}{l}\text { Kondisi } \\
\text { Rumah (C3) }\end{array}$ & Pernah & 1 \\
\cline { 2 - 3 } & Bambu & 4 \\
\cline { 2 - 3 } & Papan & 3 \\
\cline { 2 - 3 } & Bata Permanen & 1 \\
\hline \multirow{3}{*}{$\begin{array}{l}\text { Jumlah } \\
\text { Tanggungan }\end{array}$} & $>8$ & 4 \\
\cline { 2 - 3 } & $6-8$ & 3 \\
\cline { 2 - 3 } & $3-5$ & 2 \\
\cline { 2 - 3 } & $1-2$ & 4 \\
\hline Jumlah & $<$ Rp. 1.000.000 & 1 \\
\hline
\end{tabular}

\begin{tabular}{|l|l|c|}
\hline \multirow{3}{*}{$\begin{array}{l}\text { Penghasilan } \\
\text { (C5) }\end{array}$} & $\begin{array}{l}\text { Rp. 1.000.000- } \\
\text { Rp. 2.000.000 }\end{array}$ & 3 \\
\cline { 2 - 3 } & $\begin{array}{l}\text { Rp. 2.000.000- } \\
\text { Rp. 3.000.000 }\end{array}$ & 2 \\
\cline { 2 - 3 } & $>$ Rp. 3.000.000 & 1 \\
\hline $\begin{array}{l}\text { Persiapan } \\
\text { Bangun } \\
\text { Rumah (C6) }\end{array}$ & Ada & 5 \\
\cline { 2 - 3 } & Tidak ada & 1 \\
\hline
\end{tabular}

3. Matrik Perbandingan Kriteria.

Langkah selanjutnya melakukan perbandingan antara elemen-elemen dengan skala 1 (satu) sampai 9 (sembilan). Perbandingan tersebut dilakukan dengan cara membuat matrik perbandingan berpasangan kriteria. Hasil analisis dari wawancara dengan pihak kelurahan menunjukkan pada tabel 4. 
Tabel 4. Matrik Perbandingan Kriteria

\begin{tabular}{|c|c|c|c|c|c|c|}
\hline Kriteria & $\mathrm{C} 1$ & $\mathrm{C} 2$ & $\mathrm{C} 3$ & $\mathrm{C} 4$ & $\mathrm{C} 5$ & $\mathrm{C} 6$ \\
\hline $\mathrm{C} 1$ & 1 & 1 & 3 & 5 & 5 & 3 \\
\hline $\mathrm{C} 2$ & $1 / 1$ & 1 & 5 & 5 & 5 & 3 \\
\hline $\mathrm{C} 3$ & $1 / 3$ & $1 / 5$ & 1 & 3 & 3 & 3 \\
\hline $\mathrm{C} 4$ & $1 / 5$ & $1 / 5$ & $1 / 3$ & 1 & 1 & 2 \\
\hline $\mathrm{C} 5$ & $1 / 5$ & $1 / 5$ & $1 / 3$ & $1 / 1$ & 1 & 3 \\
\hline $\mathrm{C} 6$ & $1 / 3$ & $1 / 3$ & $1 / 3$ & $1 / 2$ & $1 / 3$ & 1 \\
\hline
\end{tabular}

menjumlahkan nilai-nilai dari setiap

kolom pada matrik berpasangan pada tabel 5 .

Tabel 5. Jumlah Matrik Perbandingan Kriteria

\begin{tabular}{|c|c|c|c|c|c|c|}
\hline Kriteria & C1 & C2 & C3 & C4 & C5 & C6 \\
\hline C1 & 1,00 & 1,00 & 3,00 & 5,00 & 5,00 & 3,00 \\
\hline C2 & 1,00 & 1,00 & 5,00 & 5,00 & 5,00 & 3,00 \\
\hline C3 & 0,33 & 0,20 & 1,00 & 3,00 & 3,00 & 3,00 \\
\hline C4 & 0,20 & 0,20 & 0,33 & 1,00 & 1,00 & 2,00 \\
\hline C5 & 0,20 & 0,20 & 0,33 & 1,00 & 1,00 & 3,00 \\
\hline C6 & 0,33 & 0,33 & 0,33 & 0,50 & 0,33 & 1,00 \\
\hline Jumlah & 3,07 & 2,93 & 10,00 & 15,50 & 15,33 & 15,00 \\
\hline
\end{tabular}

4. Normalisasi Matrik.

Menghitung normalisasi matrik perbandingan didapat dari setiap kolom kriteria dibagi nilai jumlah kolom $X_{J}^{*}=\frac{\mathrm{Xij}^{\mathrm{ij}}}{\sqrt{\sum_{i=1}^{m} X_{i f}^{z}(j=1,2, \ldots, n)}}$ dapat dilihat pada tabel 6 .

\section{Tabel 6. Normalisasi Matrik}

\begin{tabular}{|c|c|c|c|c|c|c|}
\hline $\begin{array}{c}\text { Krit } \\
\text { eria }\end{array}$ & $\mathrm{C} 1$ & $\mathrm{C} 2$ & $\mathrm{C} 3$ & $\mathrm{C} 4$ & $\mathrm{C} 5$ & $\mathrm{C} 6$ \\
\hline $\mathrm{C} 1$ & $\begin{array}{c}0,32 \\
6\end{array}$ & $\begin{array}{c}0,34 \\
1\end{array}$ & $\begin{array}{c}0,30 \\
0\end{array}$ & $\begin{array}{c}0,32 \\
3\end{array}$ & $\begin{array}{c}0,32 \\
6\end{array}$ & $\begin{array}{c}0,20 \\
0\end{array}$ \\
\hline $\mathrm{C} 2$ & $\begin{array}{c}0,32 \\
6\end{array}$ & $\begin{array}{c}0,34 \\
1\end{array}$ & $\begin{array}{c}0,50 \\
0\end{array}$ & $\begin{array}{c}0,32 \\
3\end{array}$ & $\begin{array}{c}0,32 \\
6\end{array}$ & $\begin{array}{c}0,20 \\
0\end{array}$ \\
\hline $\mathrm{C} 3$ & 0,10 & 0,06 & 0,10 & 0,19 & 0,19 & 0,20 \\
& 9 & 8 & 0 & 4 & 6 & 0 \\
\hline $\mathrm{C} 4$ & 0,06 & 0,06 & 0,03 & 0,06 & 0,06 & 0,13 \\
$\mathrm{C} 5$ & 0,06 & 0,06 & 0,03 & 0,06 & 0,06 & 0,20 \\
$\mathrm{C} 5$ & 5 & 8 & 3 & 5 & 5 & 0 \\
\hline $\mathrm{C} 6$ & $\begin{array}{c}0,10 \\
9\end{array}$ & $\begin{array}{c}0,11 \\
4\end{array}$ & $\begin{array}{c}0,03 \\
3\end{array}$ & $\begin{array}{c}0,03 \\
2\end{array}$ & $\begin{array}{c}0,02 \\
2\end{array}$ & $\begin{array}{c}0,06 \\
7\end{array}$ \\
\hline
\end{tabular}

5. Mengukur Nilai Konsisten.

Memeriksa konsistensi hierarki rasio konsistensi (CI/IR) dengan tahap sebagai berikut :

a. Menghitung jumlah baris dengan cara menjumlahkan tiap kolom. Hasilnya setelah dijumlahkan : K1 $=1.816, \mathrm{~K} 2=2,016, \mathrm{~K} 3=0.866$, $\mathrm{K} 4=0.430, \mathrm{~K} 5=0.496, \mathrm{~K} 6=$ 0.376 .

b. Menghitung bobot prioritas dengan cara tiap kolom matriks perbandingan berpasangan pada baris yang sama kemudian dibagi dengan jumlah kriteria yang digunakan, hasilnya sebagai berikut : $\mathrm{K} 1=0.303, \mathrm{~K} 2=0.336$, $\mathrm{K} 3=0.144, \mathrm{~K} 4=0.072, \mathrm{~K} 5=$ $0.083, \mathrm{~K} 6=0.063$.

c. Menghitung Lamda kepentingan tiap kriteria dengan cara tiap kolom matrik perbandingan dikali dengan bobot prioritas. Jumlah lamda yang digunakan untuk eigen maksimum yaitu

$6.714+6.907+6.676+6.361+6.265+$ $6.172=39.094$.

6. Eigen maksimum ( $\lambda$ maksimum).

Menghitung nilai eigen maksimum ( $\lambda$ maksimum) dengan cara total jumlah nilai eigen dibagi banyaknya kriteria yang digunakan dengan cara berikut : 
$\lambda$ maks $=\frac{39,094}{6}=6,516$

Karena matriks terdiri dari 6 kriteria, maka tahap selanjutnya yaitu :

a. Menghitung Consistency index (CI).

$$
C I=\frac{(6,516-6)}{6-1}=0,103
$$

b. Menghitung Consistency Ratio (CR).

Untuk mengetahui CR ditentukan oleh nilai Index Random Consistency. Nilai IR bergantung pada jumlah kriteria, sehingga IR yang digunakan yaitu $n=6, I R=$ 1,24 .

$C R=\frac{0,104}{1,24}=0,084$

c. Berdasarkan hasil $\mathrm{CR}$ bernilai kurang dari 0,1 maka hasil perhitungan dapat dinyatakan benar (Konsisten).

\subsection{Tahapan Metode MOORA.}

Berdasarkan hasil proses tahapan metode AHP yang digunakan untuk mencari bobot prioritas kriteria, maka proses selanjutnya adalah mencari nilai ranking dengan menggunakan metode MOORA, tahapannya sebagai berikut :

1. Data Penerima Bedah Rumah.

Berikut ini data hasil survei calon penerima bedah rumah yang akan digunakan dalam matrik ada tabel 7.
Tabel 7. Hasil Survei

\begin{tabular}{|l|c|c|c|c|c|c|}
\hline \multirow{2}{*}{ Alternatif } & \multicolumn{7}{|c|}{ Kriteria } \\
\cline { 2 - 7 } & C1 & C2 & C3 & C4 & C5 & C6 \\
\hline A1 & 5 & 5 & 4 & 3 & 3 & 5 \\
\hline A2 & 5 & 5 & 4 & 1 & 4 & 5 \\
\hline A3 & 5 & 5 & 3 & 4 & 3 & 5 \\
\hline A4 & 2 & 5 & 3 & 1 & 3 & 5 \\
\hline A5 & 5 & 5 & 4 & 3 & 3 & 5 \\
\hline A6 & 5 & 5 & 4 & 1 & 3 & 5 \\
\hline A7 & 2 & 5 & 3 & 1 & 3 & 5 \\
\hline A8 & 5 & 5 & 3 & 3 & 4 & 5 \\
\hline A9 & 2 & 5 & 4 & 3 & 1 & 5 \\
\hline A10 & 5 & 5 & 3 & 3 & 3 & 5 \\
\hline
\end{tabular}

Keterangan :

A1 - A10 : Calon penerima bedah rumah

2. Nomalisasi Matrik.

Berdasarkan persamaan

sebelumnya, maka didapatkan hasilnya seperti terlihat pada tabel 8 .

Tabel 8. Normalisasi Matrik

\begin{tabular}{|l|c|c|c|c|c|c|}
\hline \multirow{2}{*}{ Alternatif } & \multicolumn{6}{|c|}{ Kriteria } \\
\cline { 2 - 7 } & $\mathbf{C 1}$ & $\mathbf{C 2}$ & $\mathbf{C 3}$ & $\mathbf{C 4}$ & $\mathbf{C 5}$ & $\mathbf{C 6}$ \\
\hline A1 & 0,366 & 0,316 & 0,358 & 0,372 & 0,306 & 0,316 \\
\hline A2 & 0,366 & 0,316 & 0,358 & 0,124 & 0,408 & 0,316 \\
\hline A3 & 0,366 & 0,316 & 0,268 & 0,496 & 0,306 & 0,316 \\
\hline A4 & 0,146 & 0,316 & 0,268 & 0,124 & 0,306 & 0,316 \\
\hline A5 & 0,366 & 0,316 & 0,358 & 0,372 & 0,306 & 0,316 \\
\hline A6 & 0,366 & 0,316 & 0,358 & 0,124 & 0,306 & 0,316 \\
\hline A7 & 0,146 & 0,316 & 0,268 & 0,124 & 0,306 & 0,316 \\
\hline A8 & 0,366 & 0,316 & 0,268 & 0,372 & 0,408 & 0,316 \\
\hline A9 & 0,146 & 0,316 & 0,358 & 0,372 & 0,102 & 0,316 \\
\hline A10 & 0,366 & 0,316 & 0,268 & 0,372 & 0,306 & 0,316 \\
\hline
\end{tabular}

3. Mengoptimalkan atribut.

Selanjutnya adalah mencari nilai optimal dengan jumlah nilai setiap normalisasi dikali dengan bobot kriteria yang didapat dari metode AHP, berikut hasilnya pada tabel 9 . 
Tabel 9. Nilai Optimal

\begin{tabular}{|c|c|c|c|c|c|c|}
\hline \multirow{2}{*}{ Alternatif } & \multicolumn{6}{|c|}{ Kriteria } \\
\cline { 2 - 7 } & C1 & C2 & C3 & C4 & C5 & C6 \\
\hline A1 & 0,111 & 0,106 & 0,052 & 0,027 & 0,025 & 0,020 \\
\hline A2 & 0,111 & 0,106 & 0,052 & 0,009 & 0,034 & 0,020 \\
\hline A3 & 0,111 & 0,106 & 0,039 & 0,036 & 0,025 & 0,020 \\
\hline A4 & 0,044 & 0,106 & 0,039 & 0,009 & 0,025 & 0,020 \\
\hline A5 & 0,111 & 0,106 & 0,052 & 0,027 & 0,025 & 0,020 \\
\hline A6 & 0,111 & 0,106 & 0,052 & 0,009 & 0,025 & 0,020 \\
\hline A7 & 0,044 & 0,106 & 0,039 & 0,009 & 0,025 & 0,020 \\
\hline A8 & 0,111 & 0,106 & 0,039 & 0,027 & 0,034 & 0,020 \\
\hline A9 & 0,044 & 0,106 & 0,052 & 0,027 & 0,008 & 0,020 \\
\hline A10 & 0,111 & 0,106 & 0,039 & 0,027 & 0,025 & 0,020 \\
\hline
\end{tabular}

4. Ranking Nilai Alternatif.

Langkah selanjutnya adalah mencari ranking nilai alternatif. hasil pada tabel 10.

Tabel 10. Hasil Ranking Alternatif

\begin{tabular}{|l|c|c|c|}
\hline Alternatif & Maks( C1+C2+C3+C4+C6) & Min (C5) & Hasil \\
\hline A1 & 0,315 & 0,025 & 0,290 \\
\hline A2 & 0,297 & 0,034 & 0,263 \\
\hline A3 & 0,311 & 0,025 & 0,286 \\
\hline A4 & 0,218 & 0,025 & 0,193 \\
\hline A5 & 0,315 & 0,025 & 0,290 \\
\hline A6 & 0,297 & 0,025 & 0,272 \\
\hline A7 & 0,218 & 0,025 & 0,193 \\
\hline A8 & 0,302 & 0,034 & 0,268 \\
\hline A9 & 0,249 & 0,008 & 0,240 \\
\hline A10 & 0,302 & 0,025 & 0,277 \\
\hline
\end{tabular}

5. Status Kelayakan Bantuan Bedah Rumah.

Berikutnya dari hasil total nilai setiap alternatif dapat menentukan statusnya, dengan rentang nilai. Rentang nilai >= 0.25 maka statusnya layak, jika rentang nilai $<0.25$ maka status tidak layak. Sehingga status penerima bedah rumah dapat dilihat pada tabel 11

Tabel 11. Status Kelayakan

\begin{tabular}{|l|c|c|}
\hline Alternatif & Hasil & Status \\
\hline A1 & 0,290 & Layak \\
\hline A2 & 0,263 & Layak \\
\hline A3 & 0,286 & Layak \\
\hline A4 & 0,193 & Tidak layak \\
\hline A5 & 0,290 & Layak \\
\hline A6 & 0,272 & Layak \\
\hline A7 & 0,193 & Tidak layak \\
\hline A8 & 0,268 & Layak \\
\hline A9 & 0,240 & Tidak layak \\
\hline A10 & 0,277 & Layak \\
\hline
\end{tabular}

\section{SimpUlan}

Sistem penilaian penerima bedah rumah dengan menggunakan metode Analytical Hierarchy Process (AHP) untuk perhitungan bobot tiap kriteria dan metode Multi Objective Optimization on The Basis of Ratio Analysis MOORA yang digunakan untuk nilai perangkingan, dapat digunakan sebagai salah satu sistem yang membantu keputusan yang tepat. Berdasarkan hasil penelitian didapatkan 7 calon penerima bantuan bedah rumah yang layak menerima dan sisanya tidak layak menerima bantuan bedah rumah.

Penggabungan dua metode tersebut lebih akurat karena berdasarkan pada nilai kriteria dan bobot yang sebelumnya sudah diuji konsisten tidaknya terlebih dahulu. 


\section{DAFTAR PUSTAKA}

[1] Z. Aras and Sarjono, "Analisis Data Mining Untuk Menentukan Kelompok Prioritas Penerima Bantuan Bedah Rumah Menggunakan Metode Clustering K-Means( Studi Kasus: Kantor Kecamatan Bahar Utara)," $J$. Manaj. Sist. Inf., 2016.

[2] N. M. Sarifah, "Sistem Penunjang Keputusan Pemilihan Handphone Menggunakan Metode Analytical Hierarchy Process," J. Pilar Nusa Mandiri, 2015.

[3] Saefudin and S. Wahyuningsih, "Sistem Pendukung Keputusan Untuk Penilaian Kinerja Pegawai Menggunakan Metode Analytical Hierarchy Process (Ahp) Pada RSUD Serang," J. Sist. Inf., 2014.

[4] P. Poningsih, "Sistem Pendukung Keputusan Penentuan Ranking Kenaikan Gaji Staff Dan Karyawan," J-SAKTI (Jurnal Sains Komput. dan Inform., 2019, doi: 10.30645/j-sakti.v3i2.136.

[5] R. I. Handayani and A. Muzakir, "SISTEM PENDUKUNG KEPUTUSAN PENERIMAAN KARYAWAN DENGAN MENGGUNAKAN METODE ANALYTICAL HIERARCHY PROCESS (AHP) STUDI KASUS :
PT. VIRTUS VENTURAMA," $J$. PILAR Nusa Mandiri, 2018.

[6] M. Mesran, S. D. A. Pardede, A. Harahap, and A. P. U. Siahaan, "Sistem Pendukung Keputusan Pemilihan Peserta Jaminan Kesehatan Masyarakat (Jamkesmas) Menerapkan Metode MOORA," J. MEDIA Inform. BUDIDARMA, 2018, doi: 10.30865/mib.v2i2.595.

[7] Fitria, S. Y., \& SeptiliaArfida, H. Green Cloud Computing Ideas with Security Issues in Setting of Distributed Computing and Cloud Framework

[8] Wibowo, H., \& Indriyani, F. (2018, October). K-Nearest Neighbor Method For Monitoring Of Production And Preservation Information (Treatment) Of Rubber Tree $\quad$ Plant. In Prosiding International conference on Information Technology and Business (ICITB) (pp. 29-44).

[9] Setiawan, M. (2017, October). Metode K-Means Untuk Sistem Informasi Pengelompokan Mahasiswa Baru Pada Perguruan Tinggi. In Prosiding Seminar Nasional Darmajaya (Vol. 1, No. 1, pp. 130-145). 